\title{
PEMASARAN PRODUK SIMPANAN TABUNGAN PENDIDIKAN DAN BEASISWA (TAKAN Plus) PADA CREDIT UNION KELING KUMANG
}

\author{
Yuliana.F. Lilistian \\ Fakultas Ilmu Sosial dan Ilmu Politik Universitas Kapuas Sintang \\ Email: Yulianaunka@gmail.com
}

\begin{abstract}
Abstrak : Strategi pemasaran Credit Union harus dapat memberi gambaran yang jelas dan terarah tentang apa yang akan dilakukan perusahaan dalam menggunakan setiap kesempatan atau peluang pada beberapa pasar sasaran. Metode dalam penelitian ini menggunakan metode penelitian deskriptif. Subjek penelitian ini terdiri dari 4 (empat) orang yaitu Branch Manager, Pengurus, Staf yang melayani anggota yang menabung Takan Plus, dan anggota Takan Plus pada Credit Union Keling Kumang TP. Rumah Punyung Kabupaten Sintang. Guna memperoleh data yang akurat dan berkualitas, maka menggunakan teknik pengumpulan data yaitu teknik wawancara, observasi dan studi dokumentasi. Teknik analisisnya menggunakan analisis kualitatif. Hasil penelitian ini memperlihatkan bahwa konsep produk Tabungan Pendidikan dan Beasiswa TAKAN Plus Credit Union Keling Kumang memiliki karakteristik dan 3 kategori pemilihan tabungan pendidikan dan beasiswa yang diberikan yaitu kategori harian, masa kontrak 5 tahun dan masa kontrak 10 tahun. Segmentasi sasaran produk pada pemasaran produk simpanan Tabungan Pendidikan dan beasiswa (TAKAN Plus) Credit Union Keling Kumang dari kalangan pelajar dan mahasiswa sebagai user yang menerima bantuan pendidikan dan beasiswa. Pemasaran promosi pada produk simpanan Tabungan Pendidikan dan Beasiswa (TAKAN Plus) dilakukan dengan cara menggunakan metode Personal Selling dan Mass Selling. Kesimpulan penelitian pemasaran produk simpanan tabungan pendidikan dan beasiswa (TAKAN Plus) pada Credit Union Keling Kumang Tempat Pelayanan Rumah Punyung Sungai Durian Sintang dengan melihat kepada aspek konsep produk, segmentasi sasaran produk, dan promosi produk. Pemasaran Produk Simpanan TAKAN Plus dapat berjalan seperti yang diharapkan, maka penulis memberikan saran agar semakin meningkatkan cara pemasaran produk simpananTabungan Pendidikan dan Beasiswa TAKAN Plus yang sudah berlaku selama ini agar produk ini semakin dikenal dan diminati oleh anggota khususnya bagi kalangan pelajar dan mahasiswa sehingga Core Values, nilai-nilai inti Credit Union Keling Kumang dapat tercapai.
\end{abstract}

Kata Kunci : Pemasaran, Produk, Tabungan

\section{LATAR BELAKANG}

Dewasa ini telah banyak penyediaan koperasi dengan berbagai jenis diantaranya adalah jenis usaha baik dibidang jasa, perdagangan, maupun industri. Pengembangan koperasi sangat penting dalam mendukung pembangunan ekonomi suatu negara yakni untuk mengurangi masalah kesenjangan pendapatan dan mampu memperluas basis ekonomi serta dapat memberikan kontribusi yang siginifikan dalam mempercepat pertumbuhan struktural ekonomi. Koperasi sebagai salah satu bentuk badan usaha mempunyai peran strategis bagi pemberdayaan dan penguatan perekonomian rakyat. Koperasi merupakan Badan Usaha Bersama yang bergerak dalam bidang perekonomian, beranggotakan mereka yang umumnya berekonomi lemah, yang bergabung secara sukarela, berdasarkan persamaan hak dan kewajiban untuk melakukan suatu usaha yang bertujuan memenuhi kebutuhan-kebutuhan para anggotanya. Melalui wadah koperasi inilah para anggota dapat melakukan usaha-usaha untuk meningkatkan kesejahteraan bersama. Dengan semangat kebersamaan inilah koperasi hadir dan diperlukan guna mendorong tumbuhnya usaha-usaha kecil di masyarakat.

Secara nasional, Credit Union di Indonesia kini bukan lagi sekedar lembaga keuangan, tetapi sudah menjadi gerakan ekonomi karena besar dan luasnya dampak yang dihasilkannya. Secara kuantitas, sampai Oktober 2019 menurut data dari Induk Koperasi Kredit Indonesia (Inkopdit) terdapat 964.048 orang anggota dengan asset sekitar Rp.6 triliun yang tersebar di 965 Kopdit primer. Saat ini Inkopdit memiliki jaringan 30 Puskopdit/ Pra Puskopdit/ BK3D yang tersebar di beberapa Propinsi di seluruh Indonesia.

Seperti diketahui keadaan dunia usaha bersifat dinamis, yang diwarnai dengan adanya perubahan dari waktu ke waktu dan adanya keterkaitan antara satu dengan lainnya. Demikian 
pula, dengan Credit Union sehingga strategi pemasaran mempunyai peranan yang sangat penting untuk keberhasilan usaha. Strategi pemasaran Credit Union yang ditetapkan harus ditinjau dan dikembangkan sesuai dengan perkembangan pasar dan lingkungan pasar tersebut. Dengan demikian strategi pemasaran Credit Union harus dapat memberi gambaran yang jelas dan terarah tentang apa yang akan dilakukan perusahaan dalam menggunakan setiap kesempatan atau peluang pada beberapa pasar sasaran. Dalam Credit Union yang sangat penting dan saling berkaitan, guna dapat berhasilnya kegiatan pemasaran yang dilakukan oleh suatu perusahaan, yaitu sasaran yang dituju (target market) dalam hal ini adalah anggota dari Credit Union, dan juga acuan pemasaran Credit Union yang dijalankan (marketing mix) untuk sasaran tersebut. Semua aktivitas yang dilakukan di bidang pemasaran Credit Union ditujukan untuk menentukan produk (product), harga (price), promosi (promotion), dan tempat (place).

Credit Union Keling Kumang TP. Rumah Punyung yang terletak di Daerah Sungai Durian Sintang merupakan salah satu koperasi simpan pinjam keuangan yang turut memberikan pelayanan kepada anggotanya melalui usaha simpan pinjam yang secara konsisten menerapkan jati diri koperasi, tata kelola Credit Union yang sehat, rencana suksesi dalam empat pilar Credit Union yaitu pendidikan, swadaya, solidaritas, dan inovasi. Credit Union Keling Kumang TP. Rumah Punyung Sungai Durian Sintang memiliki karyawan sebanyak 12 orang, terdiri dari 5 orang perempuan dan 7 orang laki-laki yang melayani anggota sebanyak 114.377 orang dengan asset sebesar Rp. 135.144.538.372,- dengan pinjaman beredar tiap bulan Rp. 81.097.164.250,- yang didukung oleh beberapa jenis produk simpanan dan pinjaman unggulan.

Jenis/produk pinjaman yang ada di Credit Union Keling Kumang berdasarkan dari Pola Kebijakan (Poljak) Tahun 2019 adalah Suka Syariah, Pinjaman Gadai, dan KPR (Kredit Pemilikan Rumah). Sementara itu, jenis produk simpanan di Credit Union Keling Kumang berdasarkan pada Pola Kebijakan (Poljak) Tahun 2019 adalah : Simpanan Saham (Simpanan Pokok dan Simpanan Wajib), Siska (Simpanan Sukarela), Simpar (Simpanan Harian), Peridi (Simpanan Sukarela Berjangka), Takan Plus (Tabungan Pendidikan dan Beasiswa), Taroh (Simpanan Kolektif,Kelompok), Tameng (Tabungan Mingguan/ Harian), Permata (Tabungan Perumahan Anggota) dan Tanera (Tabungan Era Replanting Kelapa Sawit). Banyaknya persaingan yang ada di antara credit Union, yang memiliki produk simpanan yang sama membuat Credit Union Keling Kumang harus melakukan pemasaran aktif sehingga produknya tetap diminati oleh anggota salah satunya adalah produk Tabungan Pendidikan dan Beasiswa yang dalam Pola Kebijakan Tahun 2019 disingkat dengan nama TAKAN Plus. Tabungan ini diperuntukkan bagi para pelajar dan mahasiswa untuk membiayai biaya pendidikan dan juga memperoleh beasiswa selama pendidikan. Pada tahun 2014, saldo yang diperoleh dari Tabungan Pendidikan adalah sebesar Rp 1.316.661.780,-(Satu Milyar Tiga Ratus Enam Belas Juta Enam Ratus Enam Pulug Satu Ribu Tujuh Ratus Delapan Puluh Rupiah) bila dilihat dari jumlah anggota Credit Union Keling Kumang sebanyak 126.023 orang, maka yang bergabung didalam Tabungan Pendidikan masih sebesar 30\% dari total anggota yang ada. Dari data yang terlihat, Credit Union Keling Kumang perlu memerlukan pemasaran yang menunjang bagi peningkatan produk TAKAN Plus.

Perusahaan harus mampu menghadapi pengaruh lingkungan yang selalu berubah bahkan dengan mengantisipasi secara dini perubahanperubahan yang akan terjadi baik secara lokal, nasional, regional, maupun internasional oleh karena itu perusahaan diharapkan mampu menciptakan suatu peluang pasar yang menguntungkan bagi pengembangan usaha pemasaran pada saat ini maupun masa yang akan datang. Namun sebaliknya jika perusahaan khususnya bidang pemasaran tidak mampu menghadapi pengaruh lingkungan yang selalu berubah, maka akan menciptakan tantangan serius bahkan malapetaka bagi perusahaan secara keseluruhan untuk mempertahankan kelangsungan hidupnya.

Keberhasilan perusahaan dalam melaksanakan kegiatan umumnya dan kegiatan pemasaran pada khususnya tidak terlepas dari usaha untuk menghadapi dan mengadaptasi dengan perkembangan lingkungan di mana perusahaan berada. Hal ini disebabkan, karena banyak sekali faktor dan aspek yang mempengaruhi keberhasilan ataupun keambrukan perusahaan umumnya dan pemasaran pada khususnya sebagai akibat dari kemampuan atau ketidakmampuan perusahaan dalam menghadapi pengaruh lingkungan yang begitu cepat berubah, sehingga tingkat kemampuan ataupun ketidakmampuan dalam menghadapi pengaruh lingkungan tersebut bisa menghasilkan peluang ataupun tantangan bagi perusahaan dalam melaksanakan kegiatan perusahaan umumnya dan kegiatan pemasaran pada khususnya.

Hal utama yang menjadi dasar perlu adanya konsep pemasaran bagi perusahaan adalah karena produk yang dihasilkannya tidak bisa mencari konsumennya sendiri. Oleh karena itu, 
keinginan dan kepuasan pelanggan harus benarbenar diperhatikan. Menurut Kotler (2000:7), pemasaran adalah suatu proses sosial dan manajerial yang didalamnya individu dan kelompok mendapatkan apa yang mereka butuhkan dan inginkan dengan menciptakan, menawarkan dan mempertukarkan produk yang bernilai dengan pihak lain. Sedangkan arti pemasaran menurut Alma (2000:26) yaitu sebagai suatu proses perpindahan barang atau jasa dari tangan produsen ke tangan konsumen. Atau dapat dikatakan pula bahwa pemasaran adalah semua kegiatan usaha yang bertalian dengan arus penyerahan barang dan jasajasa dari produsen ke konsumen. Menurut Dharmesta dan Irawan (2005:13) mengemukakan bahwa pemasaran merupakan penghubung antara organisasi dengan konsumennya. Peran penghubung ini akan berhasil bila semua upaya pemasaran diorientasikan kepada pasar.

Dalam perkembangannya, koperasi diharapkan mampu berperan sebagai sokoguru perekonomian nasional di samping bentuk-bentuk usaha lainnya. Keberadaan koperasi dalam dunia usaha dan perdagangan, adalah sangatlah penting dan strategis untuk menggerakkan dan mengarahkan kegiatan pembangunan di bidang ekonomi, terutama dalam rangka menghadapi arus globalisasi dan liberalisasi perekonomian dunia yang semakin kompleks. Dalam Pasal 4 UndangUndang Nomor 17 Tahun 2012, disebutkan dengan jelas bahwa tujuan koperasi adalah "Koperasi bertujuan meningkatkan kesejahteraan Anggota pada khususnya dan masyarakat pada umumnya, sekaligus sebagai bagian yang tidak terpisahkan dari tatanan perekonomian nasional yang demokratis dan berkeadilan." Koperasi merupakan badan hukum yang didirikan berdasarkan asas kekeluargaan, melakukan kegiatan usaha dengan modal dasar yang seluruhnya terbagi dalam modal sendiri (simpanan pokok dan simpanan wajib, dana cadangan, dan hibah), modal pinjaman, dan memenuhi persyaratan yang ditetapkan dalam undang-undang serta peraturan pelaksanaannya.

Dalam sejarah koperasi Indonesia dapat ditarik suatu benang merah bahwa koperasi Indonesia lahir dan tumbuh dari "proses simpan pinjam". Artinya, koperasi yang ada saat ini diawali dari adanya kegiatan simpan pinjam. Koperasi Simpan Pinjam merupakan embrio berkembang-mekarnya suatu koperasi. Salah satu bentuk koperasi seperti tersebut di atas adalah koperasi kredit atau Credit Union. Koperasi Simpan Pinjam merupakan salah satu jenis koperasi yang mengacu pada Peraturan Pemerintah Nomor 9 Tahun 1995 tentang Pelaksanaan Kegiatan Usaha Simpan Pinjam oleh Koperasi dan Keputusan Menteri Koperasi Pengusaha Kecil dan Menengah 8 Republik Indonesia Nomor: 351/Kep/ M/XII/1998 tentang Petunjuk Pelaksanaan Kegiatan Usaha Simpan Pinjam oleh Koperasi. Kemudahan dalam perijinan pendirian koperasi telah mendorong semakin banyaknya berdiri koperasi salah satunya adalah Koperasi Simpan Pinjam. Saat ini banyak dijumpai Koperasi Simpan Pinjam yang bermunculan di seluruh pelosok Negara Indonesia. Seiring berjalannya waktu, jati diri koperasi sebagai badan usaha "dari anggota, oleh anggota dan untuk anggota" dinilai semakin pudar. Koperasi Simpan Pinjam yang ada lebih berorientasi pada keuntungan atau laba yang tinggi, bukan pada kemakmuran anggotanya. Semakin banyak Koperasi Simpan Pinjam yang berdiri, semakin ketat pula persaingan antar sesama Koperasi Simpan Pinjam. Mereka saling berinovasi dan berlomba-lomba menawarkan berbagai bentuk investasi simpanan untuk mencari calon-calon anggota. Eksistensi Credit Union (CU) semakin mengurita dan bahkan menjadi ancaman serius bagi dunia perbankan. Menurut data Rapat Anggota Tahunan Nasional Induk Koperasi Kredit Indonesia (Inkopdit) tahun 2009, anggota CU di seluruh Indonesia ada 964.048 orang yang tersebar di 965 CU.

Untuk memahami keinginan dan kebutuhan anggota Koperasi Kredit agar produk sesuai bagi anggota sehingga produk tersebut dapat terjual diperlukan suatu kegiatan pemasaran. Bahwa pemasaran bertujuan untuk mengetahui dan memahami anggota sedemikian rupa sehingga produk yang ditawarkan cocok dengan anggota. Intinya, pemasaran adalah kegiatan manusia yang diarahkan untuk memenuhi dan memuaskan kebutuhan dan keinginan melalui proses pertukaran.

\section{Konsep Produk}

Manusia memenuhi kebutuhan dan keinginan mereka dengan barang dan jasa. Menurut Kotler (2007:166), produk adalah segala sesuatu yang dapat ditawarkan pada pasar dalam upaya memenuhi keinginan dan kebutuhan konsumen. Produk yang ditawarkan tersebut meliputi: barang fisik, jasa, orang/pribadi, organisasi, dan ide. Secara lebih rinci, konsep produk meliputi: barang, kemasan, merk, warna, label, harga, kualitas, pelayanan dan jaminan. Produk yang diharapkan adalah himpunan karakter yang secara normal diinginkan oleh pemakai. Setiap produk dapat 
diklasifikasikan berdasarkan daya tahan mereka, yakni barang tahan lama, barang tidak tahan lama dan jasa.

Sejalan dengan pendapat diatas, Gitosudarmo (2008:182) menyatakan bahwa produk yang dihasilkan adalah barang atau jasa untuk mendapatkan perhatian, permintaan, pemakaian, atau konsumsi yang dapat memenuhi keinginan atau kebutuhan. Pembeli akan membeli kalau merasa cocok. Karena itu, produk harus disesuaikan dengan keinginan ataupun kebutuhan pembeli agar pemasaran produk berhasil.

Agar strategi produk dapat lebih efektif menurut Lupiyoadi (2001:77) dalam rangka mempengaruhi konsumen untuk tertarik dan membeli kemudian mereka menjadi puas, maka harus mengetahui beberapa hal tentang strategi ini, yaitu sebagai berikut : 1) Konsep produk; Konsep produk merupakan suatu pengertian atau pandangan konsumen terhadap suatu produk yang dibutuhkan dan diinginkannya. Konsumen akan memiliki konsep atau pandangan tertentu terhadap suatu barang. 2) Siklus kehidupan produk; Setiap produk sebenarnya akan memiliki siklus perputaran terhadap kehidupannya. Setiap produk itu sebenarmya dapat di ikuti perkembangan hidupnya seperti manusia saja, yaitu memiliki tahap-tahap anak-anak, kemudian tumbuh berkembang menjadi remaja, kemudian menjadi dewasa lalu surut menjadi tua dan akhirnya meninggal. Tahap yang paling awal dari masa hidupnya suatu produk dimulai dari suatu tahap yang disebut sebagai tahap perkenalan atau introduction. Pada masa ini produk tersebut baru diperkenalkan oleh pengusaha kepada masyarakat. Tahap berikutnya tahap pertumbuhan, di mana pada tahap ini merupakan kelanjutan dari tahap perkenalan yang berhasil. Setelah banyak anggota masyarakat yang mengenal akan produk itu maka diharapkan masyarakat tersebut akan menjadi menyenangi produk tersebut dan apabila hal ini terjadi maka produk tersebut akan berada pada tahap pertumbuhan. Tahap berikutnya lagi adalah menginjak pada tahap kedewasaan atau "Maturity". Tahap ini menunjukkan adanya masa kejenuhan di mana masyarakat atau konsumen sudah jenuh sehingga akan menjadi sukar untuk meningkatkan penjualan produk tersebut. Tahap yang terakhir adalah tahap penurunan atau "Decline". Dalam tahap ini masyarakat sudah tidak lagi menyenangi produk tersebut sehingga penjualan akan segera merosot tajam. Hal ini akan akan terjadi apabila pengusaha tidak mampu lagi untuk mempertahankan produknya pada tahap kedewasaan. 3) Jenis-jenis produk; Agar dapat memasarkan produk dengan baik maka perlu mengetahui produk itu termasuk dalam jenis yang mana, karena masing-masing jenis produk akan memerlukan penanganan yang berbeda dalam memasarkan produk tersebut agar berhasil.

Promosi merupakan kegiatan dari pemasaran yang sangat penting karena sekarang ini kebanyakan pasar lebih banyak bersifat pasar pembeli di mana keputusan terakhir terjadinya transaksi jual beli sangat dipengaruhi oleh konsumen. Promosi adalah arus informasi atau persuasi satu arah yang dapat mengarahkan organisasi atau seseorang untuk menciptakan transaksi antara pembeli dan penjual Oleh karena itu pembeli adalah raja. Para produsen berbagai barang bersaing untuk merebut hati pembeli agar tertarik dan mau membeli barang yang dijualnya. Pada dasarnya keputusan membeli sangat dipengaruhi oleh motif-motif pertimbangan secara emosional, seperti : merasa bangga, sugesti, anganangan dan sebagainya. Tetapi bisa juga pembeli membeli secara rasional seperti: karena mempertimbangkan riwatnya, ekonomisnya, segi kepraktisan, harganya, pengangkutannya dan sebagainya.

Promosi adalah merupakan kegiatan yang ditujukan untuk mempengaruhi konsumen agar mereka dapat menjadi kenal akan produk yang ditawarkan oleh perusahaan kepada mereka dan kemudian mereka menjadi senang lalu membeli produk tersebut. Dalam Gitosudarmo (2008:187) menyatakan bahwa adapun alat-alat yang dapat dipergunakan untuk mempromosikan produknya pengusaha dapat memilih beberapa cara yaitu : 1) Advertising (Periklanan); Advertising merupakan alat utama bagi pengusaha untuk mempengaruhi konsumennya. Advertising ini dapat dilakukan oleh pengusaha lewat surat kabar, radio, majalah, bioskop, televisi ataupun dalam bentuk posterposter yang dipasang dipinggir jalan atau tempattempat yang strategis. Dengan membaca atau melihat advertensi itu diharapkan para konsumen atau calon konsumen akan terpengaruh lalu tertarik untuk membeli produk yang diadvertensikan tersebut. Oleh karena itu maka advertensi ini haruslah dibuat sedemikian rupa sehingga menarik perhatian para pembacanya. b) Promosi penjualan (sales promotion); Promosi penjualan adalah merupakan kegiatan perusahaan untuk menjajakan produk yang dipasarkannya sedemikian rupa sehingga konsumen akan mudah untuk melihatnya dan bahkan dengan cara penempatan dan pengaturan tertentu maka produk tersebut akan menarik perhatian konsumen. c) Personal selling (Penjualan 
pribadi); Personal selling merupakan kegiatan perusahaan untuk melakukan kontak langsung dengan para calon konsumennya. Dengan kontak langsung ini diharapkan akan terjadi hubungan atau interaksi yang positif antara pengusaha dengan calon konsumennya itu. Kontak langsung itu akan dapat mempengaruhi secara lebih intensif pada konsumennya karena dalam hal ini pengusaha dapat mengetahui keinginan dan selera konsumennya. d) Publisitas (publication); Publisitas merupakan cara yang biasa digunakan juga oleh pengusaha untuk membentuk pengaruh secara tidak langsung kepada konsumen agar mereka menjadi tahu dan menyenangi produk yang dipasarkannya. Cara ini dilakukan dengan cara memuat berita tentang produk atau perusahaan yang menghasilkan produk tersebut di mass media, misalnya saja berita di surat kabar, berita di radio atau televisi maupun majalah tertentu dan sebagainya. Dengan memuat berita itu maka para pembaca secara tidak sadar telah dipengaruhi oleh berita tersebut.

Tujuan utama promosi adalah menginformasikan, mempengaruhi dan membujuk serta mengingatkan pelanggan sasaran tentang perusahaan dan bauran pemasaran. Secara rinci ketiga tujuan promosi tersebut menurut Tjiptono (2009:221) dapat dijabarkan sebagai berikut:

a. Menginformasikan, dapat berupa: 1) Menginformasikan pasar mengenai keberadaan suatu produk baru, 2) Memperkenalkan cara pemakaian cara pemakaian yang baru dari suatu produk. 3) Menyampaikan perubahan harga kepada pasar, 4) Menjelaskan cara kerja suatu produk. 5) Menginformasikan jasa-jasa yang disediakan oleh perusahaan. 6) Meluruskan kesan yang keliru. 7) Mengurangi ketakutan atau kekhawatiran pembeli. 8) Membangun citra perusahaan.

b. Membujuk pelanggan sasaran untuk: 1) Membentuk pilihan merek. 2) Mengalihan pilihan ke merek tertentu. 3) Mengubah persepsi pelanggan terhadap atribut produk. 4) Mendorong pembeli untuk berbelanja saat itu juga. 5) Mendorong pembeli menerima kunjungan wiraniaga.

c. Mengingatkan, dapat berupa: 1) Mengingatkan pembeli bahwa produk yang bersangkutan dibutuhkan dibutuhkan dalam waktu dekat. 2) Mengingatkan pembelian tempat-tempat yang menjual produk perusahaan. 3) Membuat pembeli tetap ingat walaupun tidak ada kampanye iklan. 4) Menjaga agar ingatan pertama pembeli jatuh pada produk perusahaan.
Secara singkat promosi berkaitan dengan upaya untuk mengarahkan seseorang agar dapat mengenal produk perusahaan, lalu memahaminya, berubah sikap, menyukai, yakin, kemudian akhirnya membeli dan selalu ingat akan produk tersebut. Pemasaran modern menghendaki lebih daripada mengembangkan produk yang baik, menetapkan harga yang bersaing, dan memungkinkannya dijangkau pelanggan sasaran. Perusahaan juga harus mampu mengkomunikasikan diri dengan pelanggan yang ada maupun potensial. Oleh karena itu, maka perlu adanya dilakukan kegiatan promosi.

\section{METODE}

Pendekatan Penelitian dipilih dengan mempertimbangkan keserasian dengan objek yang diteliti. Setelah data terkumpul kemudian diklasifikasikan sesuai dengan jenis data, setelah itu dilakukan penyederhanaan data, pengolahan data dan baru kemudian ditarik kesimpulan akhir. Memperhatikan masalah pokok dan tujuan yang ingin dicapai dalam penelitian ini bersifat memberikan pendekatan kualitatif secara menyeluruh yang bertujuan untuk mencari informasi yang aktual sesuai dengan fakta yang terperinci tentang pemasaran produk simpanan tabungan pendidikan dan beasiswa (Takan plus) pada Credit Union Keling Kumang Tempat Pelayanan Rumah Punyung Sungai Durian Sintang, maka jenis penelitian yang sesuai untuk dipergunakan adalah jenis penelitian deskriptif. Dengan melakukan penelitian ini diharapkan dapat dilakukan berdasarkan fakta-fakta yang tampak sebagaimana adanya, apa yang dipaparkan berupa penyajian pembahasan sesuai dengan kenyataan yang terjadi pada saat penelitian dilakukan, kemudian dianalisis sehingga hasil penelitian ini hanya berlaku pada daerah penelitian saja. Jenis data yang digunakan dalam penelitian ini adalah jenis data primer karena mengambil data langsung dari sumber yang bersangkutan dan digunakan untuk kepentingan penulis untuk melakukan penelitian. Penulis menemui branch manager, pengurus kredit, kasir, dan anggota Takan Plus Credit Union Keling Kumang Tempat Pelayanan Sungai Durian Sintang dengan melakukan wawancara, observasi dan studi dokumentasi. Lokasi penelitian adalah Credit Union Keling Kumang Tempat Pelayanan Sungai Durian Sintang. Setelah diolah data dianalisis dengan analisis kualitatif.

HASIL PENELITIAN DAN PEMBAHASAN 
Kehadiran Credit Union ditengah-tengah masyarakat telah banyak memberikan perubahan positif. Diantaranya, memperbaiki manajemen pengelolaan keuangan masyarakat, khususnya masyarakat pedalaman. Maka rantai kemiskinan yang meilit masyarakat pedalaman secara perlahan tapi pasti mulai tampak putus. Mulai dari pendidikan, kesehatan, hingga pada peningkatan penghasilan. Dalam Credit Union Keling Kumang ada banyak produk yang ditawarkan untuk mengurangi rantai kemiskinan dimasyarakat salah satunya adalah melalui produk simpanan Tabungan Pendidikan dan Beasiswa (TAKAN Plus). Melalui produk ini diharapkan para orang tua mulai menyiapkan tabungan pendidikan untuk anak-anak. Hal ini bermaksud untuk menghindari kesulitan dana menyekolahkan anak-anaknya kejenjang yang lebih tinggi. Takan Plus memiliki 3 jenis pilihan. Ada simpanan pendidikan yang bersifat harian dan bulanan. Anggota bisa memilih jangka waktu kontrak 5 tahun atau 10 tahun, disesuaikan dengan kemampuan anggota.Oleh karena itu, pemasaran menjadi salah satu hal penting bagi Credit Union Keling Kumang dalam menjadikan produk simpanan Tabungan Pendidikan dan Beasiswa (TAKAN Plus) menjadi produk yang diunggulkan untuk dapat dijual dimasyarakat.

Product merupakan keseluruhan konsep objek atau proses yang memberikan sejumlah nilai manfaat bagi pelanggan. Yang perlu diperhatikan dalam product adalah pelanggan tidak hanya membeli fisik dari product itu saja, tetapi membeli benefit dan value dari product itu yang disebut The offer. terutama pada product jasa yang kita kenal tidak menimbulkan kepemilikan fisik bagi pelanggan. Tabungan merupakan simpanan yang paling popular dikalangan masyarakat umum. Dari sejak kanak-kanak kita sudah dianjurkan untuk berhidup hemat dengan cara menabung. Pada awalnya menabung masih secara sedarhana, menyimpan uang dibawah bantal atau di dalam celengan dan disimpan di rumah. Namun faktor resiko menyimpan uang di rumah begitu besar seperti resiko kehilangan atau kerusakan. Kerugian lainnya adalah menabung di rumah jumlahnya tidak akan pernah akan bertambah atau berbunga, jadi tetap saja sama seperti sejumlah uang yang disimpan.

Credit Union Keling Kumang TP. Rumah Punyung Kabupaten Sintang sudah melakukan kegiatan pemasaran konsep produk pada produk simpanan Tabungan Pendidikan. Lebih lanjut seperti dikatakan oleh Branch Manager dan Kasir yang melayani anggota, produk Tabungan
Pendidikan dan Beasiswa TAKAN Plus dengan kode produk S-5, memiliki karakteristik dan 3 kategori pemilihan tabungan pendidikan dan beasiswa yang diberikan yaitu kategori harian, masa kontrak 5 tahun dan masa kontrak 10 tahun. Setoran awal minimal TAKAN Plus adalah sesuai dengan variasi simpanan, dan BJS (Balas Jasa Simpanan) adalah sesuai dengan sesuai pilihan. Adapun karakteristiknya adalah sebagai berikut : 1) Pemilik TAKAN Plus berusia maksimal 24 tahun (masa sekolah), 2) Beli buku gratis, jika ganti buku membayar Rp 7.000,- 3) Takan Plus memiliki 3 kategori, sebagai berikut : a. TAKAN Plus A (Harian): Setoran dan Penarikan TAKAN harian dapat dilakukan tiap hari selama jam kerja, BJS Takan harian sebesar 5\% pa, Simpanan wajib setiap bulan minimal Rp 5.000,-, Saldo minimal Rp 5.000, Penutupan rekening dikenakan biaya $\mathrm{Rp} 2.000,-$. b. TAKAN Plus B (Masa kontrak 5 tahun) dan c. TAKANPlus C(Masa kontrak 10 tahun).

Ketentuan TAKAN Plus B dan C : 1) Menggunakan sertipikat sebagai bukti kepemilikan, 2) Menggunakan rekening koran, 3) Apabila menunggak setoran 1 atau 2 bulan maka yang bersangkutan bisa menyetor pada bulan berikutnya sebesar tunggakan, 4) Apabila tidak menyetor selama 3 bulan berturut-turut maka peserta TAKAN plus hanya berhak atas jumlah setoran yang masuk sampai setoran terakhir. Kontrak diputuskan. Simpanan dimasukan ke rekening TAKAN Plus A (harian), 5) Selama masa kontrak belum jatuh tempo maka uang asuransi pendidikan tidak bisa ditarik, 6) Biaya pemutusan kontrak (penarikan) sebelum jatuh tempo dikenakan biaya finalty sebesar $1 \%$ dari saldo TAKAN Plus yang cair. 7) Takan Plus bisa disetor melebihi setoran wajib berdasarkan kelipatan setoran. 8) Jika anggota TAKAN Plus meninggal dunia maka anggota berhak atas beasiswa anggota berdasarkan jumlah setoran hingga setoran terakhir dan berhak atas santunan sebesar Rp 3.000.000,-, 9) Dapat dijadikan Jaminan Pinjaman Pendidikan (lihat ketentuan Pinjaman Pendidikan). 10) Tidak dilindungi Asuransi Simpanan (ASIM).

Pemasaran konsep produk Takan Plus memberikan keuntungan kepada anggota apabila memilih TAKAN Plus sebagai produk simpanan. Produk TAKAN Plus sebagai produk yang membantu masyarakat dibidang pendidikan sesuai dengan tujuannya sudah memiliki suatu konsep yang jelas. Tugas pemasaran Credit Union Keling Kumang TP. Rumah Punyung Kabupaten Sintang adalah mempertahankan tingkat permintaan ini di tengah perubahan selera konsumen serta meningkatnya persaingan. harus mempertahankan 
atau meningkatkan mutu produknya dan terusmenerus mengukur kepuasan konsumen untuk memperoleh kepastian bahwa semua telah berjalan dengan baik.

produk TAKAN Plus sudah memiliki positioning yang tepat membantu anggota untuk melanjutkan pendidikan ke jenjang yang lebih tinggi. Positioning itu sendiri strategi untuk merebut posisi dibenak konsumen, sehingga strategi ini menyangkut bagaimana membangun kepercayaan, keyakinan, dan kompetensi bagi pelanggan. Jadi, positioning adalah suatu pernyataan mengenai bagaimana produk TAKAN Plus Credit Union Keling Kumang TP. Rumah Punyung Kabupaten Sintang tertanam dibenak anggota yang mempunyai kesesuaian dengan kompetensi yang dimiliki Credit Union Keling Kumang TP. Rumah Punyung Kabupaten Sintang untuk mendapatkan kepercayaan dan pengajuan dari anggota.

Credit Union Keling Kumang TP. Rumah Punyung Kabupaten Sintang sudah memiliki konsep produk TAKAN Plus yang jelas, dimana semua keuntungan dan kemudahan yang diperoleh anggota dengan menabung di TAKAN Plus dapat membantu anggota untuk melanjutkan pendidikan ke jenjang yang lebih tinggi, mulai dari SMP, SMA sampai ke pada perguruan tinggi. Tujuan utama strategi produk adalah agar dapat mencapai sasaran pasar yang dituju dengan meningkatkan kemampuan bersaing atau mengatasi persaingan. Anggota Credit Union Keling Kumang TP. Rumah Punyung Kabupaten Sintang memilih menabung produk simpanan TAKAN Plus, karena produk TAKAN Plus memberikan sesuai kebutuhan dan keinginannya untuk melanjutkan pendidikan ke jenjang yang lebih tinggi.

Segmentasi sasaran produk adalah proses membagi pasar keseluruhan suatu produk atau jasa yang bersifat heterogen ke dalam beberapa segmen, dimana masing-masing segmennya cenderung bersifat homogen dalam aspek. Jadi, segmentasi sasaran produk merupakan penetapan oleh perusahaan secara jelas kelompok-kelompok pasar yang sesuai untuk dilayani, selain efektif dan efisien melalui kombinasi kebijakan marketing mix yang berbeda-beda antara segmen yang satu dengan segmen yang lain. Credit Union Keling Kumang sudah melakukan segmentasi sasaran produk pada pemasaran produk simpanan Tabungan Pendidikan. Dari karakteristik TAKAN Plus yang diberikan bahwa produk ini menyisir kalangan pelajar dan mahasiswa sebagai user yang menerima bantuan pendidikan dan beasiswa. Dikatakan bahwa yang menjadi anggota adalah pelajar dan mahasiswa yang berusia maksimal 24 tahun dengan jangka waktu yang diberikan ada 3 kategori yaitu harian, kontrak 5 tahun dan kontrak 10 tahun.

Bagi pelajar dan mahasiswa yang menabung pada kategori harian, simpanan wajib setiap bulan adalah minimal Rp. 5.000,- dan balas jasa simpanan adalah sebesar 5\% pa. Sementara itu, pada kategori kontrak 5 tahun, anggota menabung dengan ketentuan dengan jumlah uang mulai dari Rp. 25.000,- s/d Rp. 200.000,- dengan jangka waktu selama 5 tahun maka berhak mendapatkan beasiswa pendidikan mulai dari Rp. 2.500.000,- s/d Rp. 20.000.000,- dan juga akan mendapatkan bantuan biaya sekolah yang dimulai pada bulan ke 36 mulai dari Rp. 100.000,- s/d Rp. 800.000,-

Untuk kategori kontrak 10 tahun bagi pelajar dan mahasiswa yang menabung pada produk TAKAN Plus, anggota wajib menabung dengan ketentuan jumlah uang mulai dari Rp. 25.000,- s/d Rp. 200.000,- dengan jangka waktu selama 10 tahun maka berhak mendapatkan beasiswa pendidikan mulai dari Rp. 5.000.000,- s/d Rp. 40.000.000,dan juga mendapatkan bantuan biaya sekolah yang dimulai pada bulan ke 72 mulai dari Rp. 200.000,s/d Rp. 1.600.000,-

Credit Union Keling Kumang TP. Rumah Punyung Kabupaten Sintang sudah memiliki segmentasi sasaran produk TAKAN Plus yang jelas, dimana produk ini membidik kalangan pelajar dan mahasiswa sebagai anggota. Dengan adanya segmentasi sasaran produk TAKAN Plus dapat merupakan strategi mengalokasikan sumber daya Credit Union Keling Kumang TP. Rumah Punyung Kabupaten Sintang secara efektif, karena sumber daya yang dimiliki masih terbatas.

Dengan menentukan segmentasi sasaran produk TAKAN Plus yang akan dituju, usaha akan lebih terarah. Oleh karena itu, membidik dan menyisir target pasar harus benar-benar pokok sehingga upaya yang dikeluarkan efektif dan efisien. Oleh karena itu sudah tepat jika Credit Union Keling Kumang TP. Rumah Punyung Kabupaten Sintang perlu mendidik pasar yang akan dimasuki yang tentunya harus sesuai dengan keunggulan daya saing yang dimiliki oleh perusahaan. Dan perlu juga memastikan bahwa segmentasi sasaran produk yang dipilih itu cukup besar dan akan cukup menguntungkan bagi Credit Union Keling Kumang TP. Rumah Punyung Kabupaten Sintang atau dapat pula memilih segmen yang pada saat ini masih kecil, tetapi menarik dan 
menguntungkan dimasa mendatang (market growth).

Strategi promosi merupakan bagian yang digunakan untuk mencapai keunggulan kompetitif karena strategi promosi adalah faktor yang mempengaruhi pemilihan produk dan jasa bagi konsumen. Keputusan konsumen akan tercapai apabila penggunaan strategi promosi untuk produk dan jasa yang diberikan sesuai dengan kebutuhan para konsumen itu sendiri. Dengan begitu maka produk dapat bersaing di pasaran, sehingga menjadikan konsumen memiliki banyak alternatif pilihan produk sebelum mengambil keputusan untuk membeli suatu produk yang ditawarkan. Hal inilah yang menjadikan peran promosi penting bagi koperasi khususnya Credit Union.

Credit Union Keling Kumang sudah melakukan kegiatan pemasaran promosi pada produk simpanan Tabungan Pendidikan dengan cara melakukan metode Personal Selling dan Mass Selling. Credit Union Keling Kumang TP. Rumah Punyung Kabupaten Sintang melakukan Personal Selling kepada para anggotanya dengan cara melakukan komunikasi langsung (tatap muka) kepada anggota baik anggota baru maupun anggota lama untuk memperkenalkan produk TAKAN Plus dan membentuk pemahaman anggota terhadap produk sehingga mereka kemudian tertarik untuk menabung pada produk tersebut.

Sementara itu, dengan melakukan Mass Selling Credit Union Keling Kumang TP. Rumah Punyung Kabupaten Sintang melakukan pendekatan yang menggunakan media komunikasi untuk menyampaikan informasi kepada khalayak ramai dalam satu waktu. Seperti yang dikemukakan oleh kasir dan anggota TAKAN Plus yang penulis temui, bahwa sebagai contoh nyata yang pernah dilakukan Credit Union Keling Kumang untuk mengenalkan produk TAKAN Plus, dalam rangka merayakan hari Raya Paskah pada bulan April 2018 yang lalu Credit Union Keling Kumang bekerjasama dengan Orang Muda Katolik (OMK) dari Gereja Katedral dan Gereja Ratu Maria Semesta Alam serta Seksi Pelayanan Pemuda (SPP) GKE Petra Sintang mengelar Paskah Oikumene Anak dengan tema "Belajar dan Mencapai Cita-cita Bersama Takan Plus" yang disiarkan oleh salah satu stasiun televisi lokal (Ruai TV) yang ada didaerah. Melalui kegiatan ini diharapkan para orang tua mulai menyiapkan tabungan pendidikan untuk anak-anak. Hal ini bermaksud untuk menghindari kesulitan dana menyekolahkan anak-anaknya kejenjang yang lebih tinggi. Kebiasaan yang terjadi adalah ketika anak-anak mau sekolah ke jenjang berikutnya orang tua sibuk mencari dana, sehingga harus kesana-kesini mencari pinjaman. Bahkan tak jarang harus jual harta benda untuk memberangkatkan anak-anaknya sekolah atau kuliah. Produk tabungan pendidikan dan beasiswa TAKAN Plus merupakan produk yang disiapkan Credit Union Keling Kumang untuk orang tua yang menyayangi anak-anaknya, sehingga cita-cita anaknya dapat tercapai.

Dalam strategi promosi pemasaran, kegiatan yang dilaksanakan dalam rangka promosi produk TAKAN Plus merupakan bentuk periklanan yang dilakukan oleh Credit Union Keling Kumang dengan memberikan informasi kepada anggota maupun masyarakat umum mengenai seluk beluk produk (Informative), kemudian juga cara tersebut langsung dapat mempengaruhi khalayak untuk bergabung menjadi anggota TAKAN Plus (persuading), juga mengingatkan kembali kepada masyarakat bahwa sudah ada tabungan pendidikan dan beasiswa yang diperuntukkan bagi kalangan pelajar dan mahasiswa (Reminding), serta dapat menciptakan suasana yang menyenangkan sewaktu khalayak menerima dan mencerna informasi mengenai pengenalan produk TAKAN Plus dengan menyertakan berbagai rangkaian kegiatan perlombaan, diantaranya; lomba mewarnai logo Credit Union Keling Kumang, lomba melukis telur, lomba gerak dan lagu serta lomba Fashion Show (Entertainment).

Dalam rangka memasarkan produk TAKAN Plus, Credit Union Keling Kumang sudah melakukan promosi dengan metode personal selling dan mass selling. Berupa komunikasi langsung atau tatap muka yang dilakukan oleh 
Credit Union Keling Kumang secara langsung. Untuk semakin menarik minat anggota dan masyarakat akan produk TAKAn Plus, Credit Union Keling Kumang gencar mengkomunikasikan produknya melalui media komunikasi seperti iklan cetak dan siaran, brosur, poster dan selebaran.

Konsep produk Tabungan Pendidikan dan Beasiswa TAKAN Plus Credit Union Keling Kumang memiliki karakteristik dan 3 kategori pemilihan tabungan pendidikan dan beasiswa yang diberikan yaitu kategori harian, masa kontrak 5 tahun dan masa kontrak 10 tahun. Segmentasi sasaran produk pada pemasaran produk simpanan Tabungan Pendidikan dan beasiswa (TAKAN Plus) Credit Union Keling Kumang dari kalangan pelajar dan mahasiswa sebagai user yang menerima bantuan pendidikan dan beasiswa. Pemasaran promosi pada produk simpanan Tabungan Pendidikan dan Beasiswa (TAKAN Plus) dilakukan dengan cara menggunakan metode Personal Selling dan Mass Selling. Dari beberapa kesimpulan diatas, maka penulis menyarankan beberapa saran sebagai berikut : Semakin meningkatkan cara pemasaran produk simpanan Tabungan Pendidikan dan Beasiswa TAKAN Plus yang sudah berlaku selama ini agar produk ini semakin dikenal dan diminati oleh anggota khususnya bagi kalangan pelajar dan mahasiswa sehingga Core Values, nilai-nilai inti Credit Union Keling Kumang dapat tercapai.

\section{DAFTAR PUSTAKA}

Arikunto, S. 2000. Prosedur Penelitian, Suatu Pendekatan Praktek. Jakarta: PT. Rineka Cipta.

Buchari, Alma. 2000. Manajemen Pemasaran dan Pemasaran Jasa, Cetakan Kelima. Bandung: Alfabeta

Dharmesta dan Irawan. 2005. Manajemen Pemasaran Modern, Edisi Kedua. Yogyakarta : Liberty

Gitosudarmo, Indriyo. 2008. Manajemen Pemasaran. Yogyakarta: BPFEYogyakarta.

Hendrojogi. 2010. Koperasi: Asas-asas, Teori dan Praktek. Jakarta: Rajawali Grafindo Persada.

Kasmir dan Jakfar. 2007. Studi Kelayakan Bisnis. Edisi Kedua. Cetakan Keempat. Jakarta: Penerbit Prenada Media group. . 2005. Manajemen Pemasaran, Jilid 1. Penerjemah, Benyamin Molan. Jakarta: Prehallindo.

Lupiyoadi, Rambat. 2001. Manajemen Pemasaran Jasa. Jakarta: Salemba Empat

Nawawi, H. 2001. Penelitian Bidang Sosial. Yogyakarta: Gadjah Mada Press

Sugiyono, 2007. Metode Penelitian Kuantitatif, Kualitatif dan $R \& D$. Jakarta: CV. Alfabeta.

Sukamdiyo, Ign dan Dasuki, Alex. 1999. Manajemen Koperasi. Jakarta: Erlangga.

Stanton, William J. 2008. Prinsip-prinsip Pemasaran. Penerjemah, Firdaus. Jakarta: Erlangga

Swastha, Basu dan Handoko. 2008. Azas-azas Marketing. Yogyakarta: Liberty

Widiyanti, Ninik. 2002. Manajemen Koperasi. Jakarta: Rineka Cipta. 